\title{
EFFECTS OF HHP PROCESSING AT 400 MPA ON PROTEINS OF LIQUID EGG PRODUCTS
}

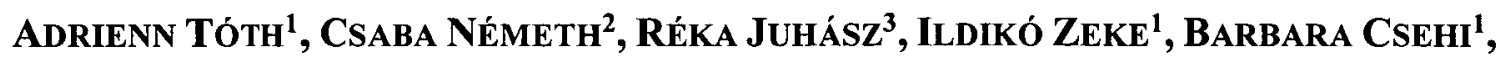 DÓRA BÉNYI ${ }^{1}$, LÁSZLÓ FRIEDRICH ${ }^{1}$}

\author{
'Szent István University Department of Refrigeration and Livestock Products' \\ Technology, Budapest Hungary \\ ${ }^{2}$ Capriovus Kft. Szigetcsép Hungary \\ ${ }^{3}$ Szent István University Department of Food Preservation \\ toth.adrienn@etk.szie.hu
}

\begin{abstract}
In food preservation technologies there are pursuits to apply minimal processing technologies which don't influence product quality attributes like protein structure.

High hydrostatic pressure (HHP) is one of the minimal processing technologies. The effect of high hydrostatic pressure (HHP) was studied at $400 \mathrm{MPa} 600 \mathrm{~s}$ on proteins of liquid egg products (egg yolk, LEY and whole egg, LWE). Thermo-physical, calorimetrical properties were examined on Micro DSC III (differential scanning calorimeter).

Our result show that whole egg's proteins are not desaturated by HHP, but $40 \%$ of egg yolk's proteins had denaturation caused by processing.

Aggregation and separation of protein groups can be observed by both products. Changes in protein structures caused texture modifications.
\end{abstract}

Keywords: high hydrostatic pressure, egg products, protein denaturation, minimal processing

\section{INTRODUCTION}

After the II World War egg production launched a sharp increase that shows nowadays a growing trend too, estimated in 2015 volume of production may be greater than 72 million tons that means 1260 trillion pieces of shell eggs (DEUTSCHE STIFTUNG WELTBEVÖLKERUNG, 2009; FAO, 2005). The growing demand justify the development of new products which are easy to store and use, have extended shelf-life and are fully satisfying the aspects of food safety.

Traditionally, eggs are marketed as shell eggs, but in recent years, egg consumption in the form of egg products has increased. These products can be classified as refrigerated liquid, frozen, and dried products (DE JESÚS ET AL., 2013). Often we crash the problem by heat treatment of egg products, that there may be surviving microorganisms which can multiply in refrigerated storage. We can solve this problem with combination of HHP and heat treatment based on research results (PILAVTEPE ET AL., 2008; WANG ET AL., 2013).

Non-thermal processes might be an excellent alternative to overcome the problems associated to the changes in egg functional properties (DE SOUZA ET AL., 2015). Similar to thermal pasteurization, non-thermal pasteurization of eggs is challenging and despite substantial efforts, and none of the non-thermal technologies has been commercialized for liquid egg products, like pulsed electric fields (WONG ET AL., 1996), electron beam radiation and gamma radiation, or high hydrostatic pressure (PONCE ET AL., 1998, AMIALI ET AL., 2006).

The aim of the present paper is to study the effect of HHP treatment of liquid egg products (liquid whole egg LWE and liquid egg yolk LEY) at $400 \mathrm{MPa}, 600 \mathrm{~s}$. Protein structure, agglomeration and denaturation are inspected 


\title{
MATERIAL AND METHOD
}

\section{Sample preparing and HHP processing}

Samples were taken from processing line of Capriovus Ltd. We used homogenized liquid whole egg (LWE) and liquid egg yolk (LEY). From every product $10-10 \mathrm{ml}$ of samples were packaged in PE bags. Samples were treated on $400 \mathrm{MPa}$ in RESATO FPU 100-2000 laboratory HHP equipment with holding times: 30, 180, 300, 420 and $600 \mathrm{~s}$ at room temperature. Samples were stored at $4-6{ }^{\circ} \mathrm{C}$ before measurements. Rising of pressure was in every case $100 \mathrm{MPa} / 60 \mathrm{~s}$, on a RESATO FPU 100-2000 HHP equipment. Treatment and measurements were at Szent István University Faculty of Food Science, Department of Refrigeration and Livestock Products Technology and Dept. of Food Preservation.

\section{Thermo-physical measurements}

Thermo-physical, calorimetrical properties were examined on Micro DSC III (differential scanning calorimeter). In each case approximately $745.5 \mathrm{mg}$ of samples were taken, reference was distillated water. Speed of heating was $1.5{ }^{\circ} \mathrm{C} / \mathrm{min}$, temperature of measuring was $95{ }^{\circ} \mathrm{C}$ and speed of cooling was $1.5^{\circ} \mathrm{C} / \mathrm{min}$, controlled by SetSoft 2000 . Callisto 7.6 software was used to evaluate DSC thermograms (Figure 1).

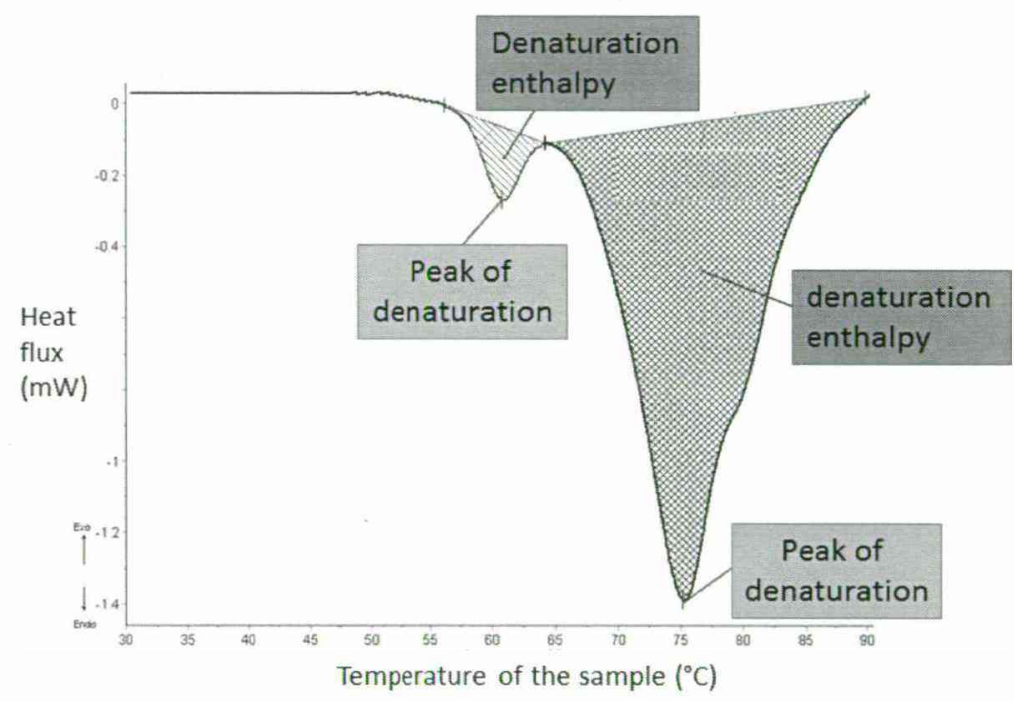

Figure 1. Overview of a thermogram

\begin{abstract}
RESULTS
In thermograms of egg products control and $400 \mathrm{MPa}, 600 \mathrm{~s}$ processed samples are shown to make an easier overview of results. In Figure 2, there can be observed that areas below the curves are from the same size: therefore there was no protein denaturation during 400 $\mathrm{MPa}$ and $600 \mathrm{~s} \mathrm{HHp}$ treatment of liquid whole egg. The shapes of the curves are different, it suggests that HHP processing caused protein aggregation and restructuration between 70 and $80^{\circ} \mathrm{C}$. In protein fraction of conalbumin $\left(55-60^{\circ} \mathrm{C}\right)$ there were no changes.
\end{abstract}




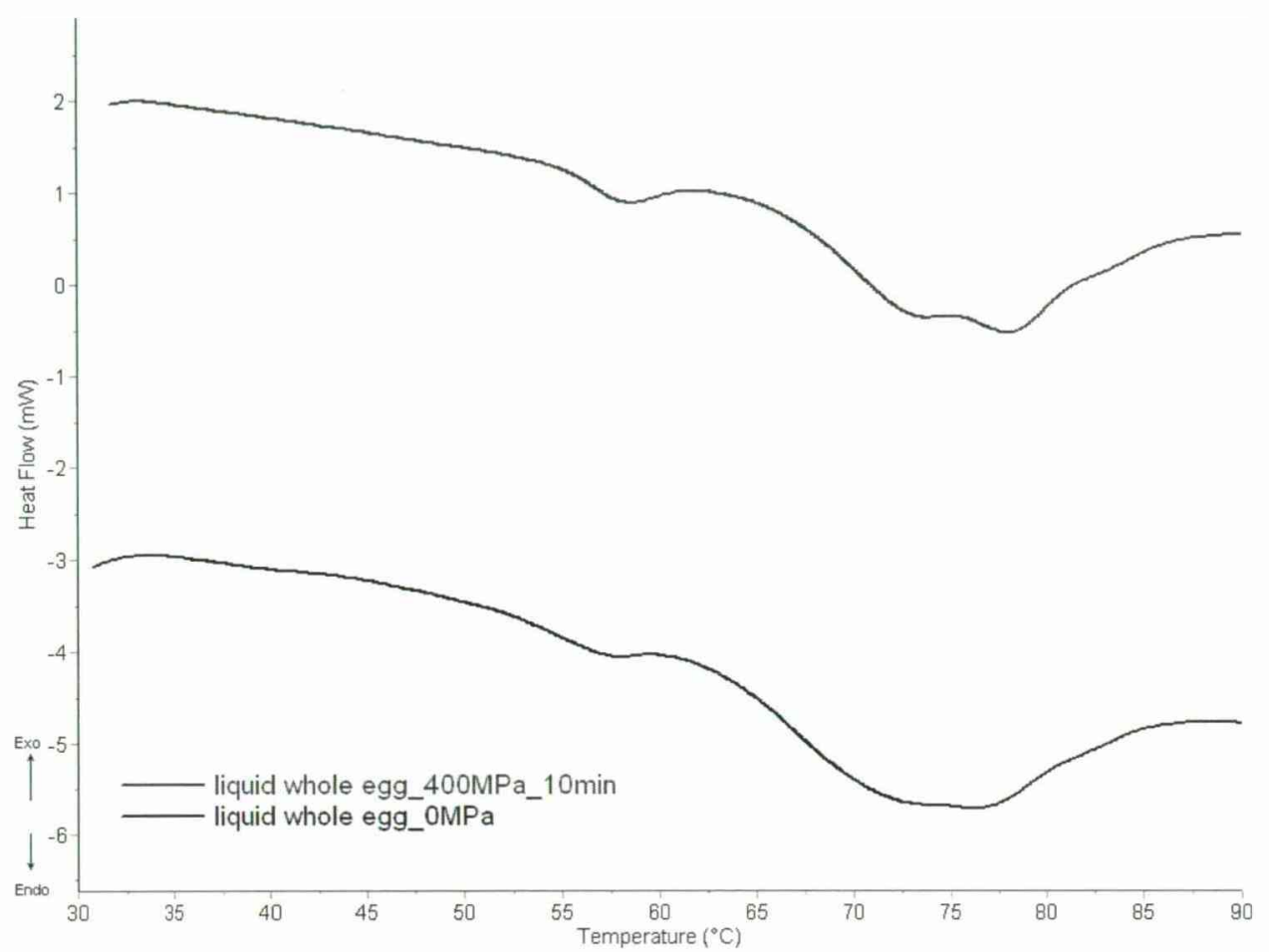

Figure 2. Thermogram of liquid whole egg control and HHP treated (400 MPa, $600 \mathrm{~s}$ )

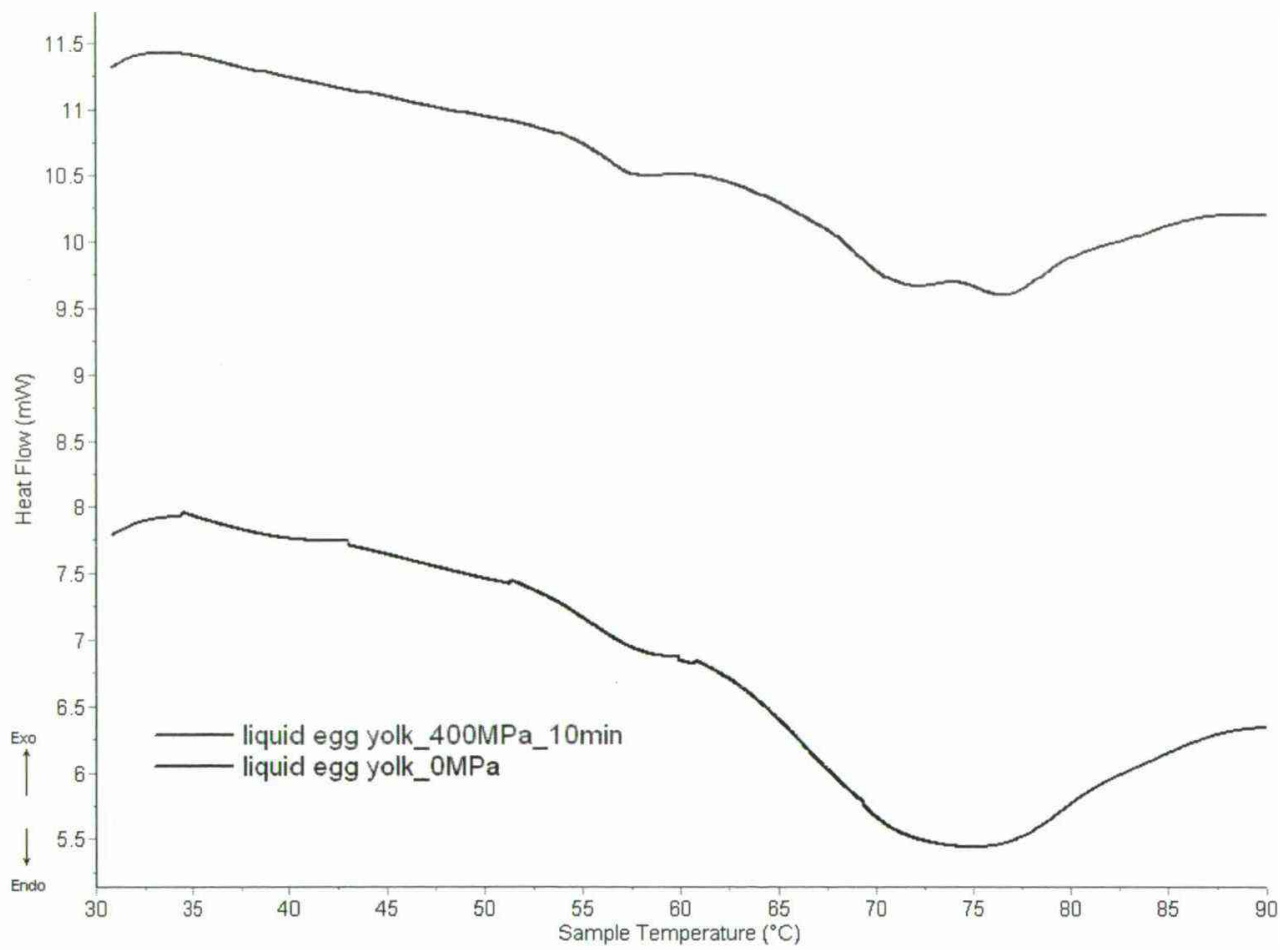

Figure 3. Thermogram of liquid egg yolk control and HHP treated (400 MPa, $600 \mathrm{~s}$ )

In Figure 3 there can be seen the thermogram of liquid egg yolk. In case of egg yolk that areas under the curves are different: HHP treated sample's curves area decreased $40 \%$. Decreasing of area means that there is denaturation of proteins in egg yolk. The main differences between the curves are at $70-80^{\circ} \mathrm{C}$. Proteins were fragmented. These fractions 
are ovalbumin according to references. Appearing of peaks in thermograms leads to the conclusion that HHP treatment may cut by Proteins.

Viscosity and texture of samples were influenced by HHP: after $600 \mathrm{~s}$ egg yolk became spreads, viscous. Liquid whole egg showed the same changes, but only in a smaller extent. Rheological changes of samples indicate that there were protein aggregation and structural changes of proteins can be appeared.

\section{CONCLUSIONS}

In our study is shown that HHP treatment of liquid whole egg and liquid egg yolk influences the protein structure and may cause denaturation. The changes of proteins can be observed in thermograms and in texture attributes. Proteins in egg have big importance in processing and quality of food products.

\section{ACKNOWLEDGEMENTS}

We owe thanks for all colleagues of Department of Refrigeration and Livestock Products Technology, Department of Food Preservation and Capriovus Ltd.

\section{REFERENCES}

Amiali, M., Ngadi, M.O., Raghavan, G.S.V., Smith, J.P. (2006): Inactivation of Escherichia coli O157:H7 and Salmonella enteritidis in liquid egg white using pulsed electric field. Journal of Food Science 71: 88-94.

Andrassy, E., Farkas, E., Seregely, Z.S., Dalmadi, I., Tuboly, E., Lebovics, V. (2006): Changes of hen eggs and their components caused by non-thermal pasteurizing treatments II. Some non-microbiological effects of gamma irradiation or hydrostatic pressure processing on liquid egg white and egg yolk. Acta Alimentaria 35(3): 305-318.

DE Jesús, M.N., Zanqui, A.B., Valderrama, P., Tanamati, A., MaruYama, S.A., DE SouzA, N.E., MATSushitA, M. (2013): Sensory and physico-chemical characteristics of desserts prepared with egg products processed by freeze and spray drying. Food Sci. Technol. 33(3): 549-554.

De Souza, P.A., Müller, A., Beniaich, A., Mayer-Miebach, E., OehlKe, K., Stahl, M., GREINER, R., FERNÁNDEZ, A. (2015): Functional properties and nutritional composition of liquid egg products treated in a coiled tube UV-C reactor. Innovative Food Science \& Emerging Technologies 32: 156-164.

DEUTSCHE STIFTUNG WELTBEVÖLKERUNG (2009), http://www.dsw-online.de/ (date OF DOWNLOAD: 2015.04.30.)

FAO (2005): 'Food and Agricultural Organization of the United Nation Statistics' (FAO STAT Data Base results), Statistical Yearbook, FAO, Rome, http://www.fao.org/economic/ess/publications-studies/statistical-yearbook/fao-statisticalyearbook-2005-2006/en/ (date of download: 2015.04.30.)

Pilavtepe-Celik, M., Balaban, M.O., AlPas, H., Yousef, A.E. (2008): Image analysis based quantification of bacterial volume change with high hydrostatic pressure. Journal of Food Science 73: 423-429. 
Ponce, E., Pla, R., Capellas, M., Guamis, B., Mor-Mur, M. (1998): Inactivation of Escherichia coli inoculated in liquid whole egg by high hydrostatic pressure. Food Microbiology 15: 265-272.

WANG, C.Y., HsU, C.P., HuANG, H.W., YANG, B.B. (2013): The relationship between inactivation and morphological damage of Salmonella enterica treated by high hydrostatic pressure, Food Research International 2: 1482-1487.

WonG, Y.C., Herald, T.J., HaChmeister, K.A. (1996): Comparison between irradiated and thermally pasteurized liquid egg whites on functional, physical and microbiological properties. Poultry Science 75: 803-808. 